\title{
THE HOP REDBUG (PARACALOCORIS HAWLEYI KNIGHT) ${ }^{1}$
}

\section{By I. Myron Hawley}

During the past few years hop plants in the yards about Waterville, N. Y., and especially in the vicinity of Sangerfield, have shown conspicuous injury to the foliage by perforations of the leaves and also by a stunting and deformation of the stems. In June, 1913, there were several yards at Sangerfield notably injured in this manner. Careful examination of the affected plants disclosed the presence of large numbers of red nymphs with white markings. When these yards were examined the first part of July, the nymphs were feeding on the vines and sap was flowing from the wounds which they had made. A few adults were taken at this time, which later were found to belong to the family Miridæ. Because of their striking color the writer has called them the hop redbug. Each year since 1913 the insect has increased greatly in numbers and caused more and more injury. It may now be found in yards ten miles from Sangerfield but does not appear to have reached the Cooperstown district, thirty miles distant.

The writer submitted a large series of specimens for examination to H. H. Knight, who reported them as representing a new species and described it as Paracalocoris hawleyi. Later the determination was confirmed by W. L. McAtee, who in addition described several varieties of the species. The drawings of the various stages are by Miss A. C. Stryke.

\section{NATURE OF THE INJURY}

The injury may be recognized by the deformed and stunted vines (Pl. 28, Fig. 1) and the irregular holes in the leaves (Pl. 28, Fig. 2). The initial injury is made evident by many light spots in the still unfolded leaves. On close examination it is found that the epidermis is broken on the under side. Later, as growth continues, a dead area is produced and, when this drops out, irregular holes result. The early work is found about the middle of June, and by the middle of July the leaves may be completely riddled.

In the later stages a nymph may feed on the vines, causing the sap to flow from the punctures. As the vine grows it will often become stunted on the side attacked, and by continuing its growth on the opposite side, a sharp bend will be formed. A plant is often weakened so that its clinging power is lost. The main stems will tend to hang down and often all the vines of the hill will slip down around the base of the pole (Pl. 28, Fig. 3). The older nymphs may also feed on the burrs

1 Contribution from Entomological Laboratory of Cornell University. 
and hop heads, but serious injury to these parts could not be detected. Pole yards are attacked worse than string yards; in string yards, the vines on the pole show more injury than those on the strings. The work of the hop redbug is similar to that described by F. V. Theobald for a related species, Calocoris fulvomaculatus Deg., which has caused some injury to the hop in England.

\section{LIFE-HISTORY}

EGG-The egg (Fig. 28) is $1.6 \mathrm{~mm}$. long, .4 mm. wide and .2 mm. thick; dirty white, curved, with two prominent, pure white, incurving hooks on the micropyle end.

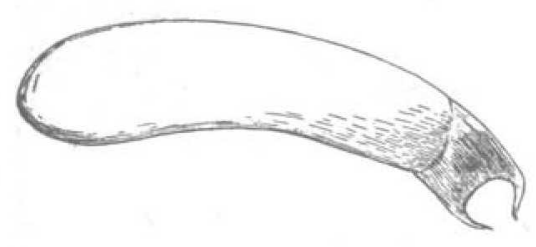

One hook is pointed and the other is blunt at the tip. The surface of the egg is smooth and glossy.

The eggs are inserted singly and in groups of two, three or four in the bark or wood of hop poles, to which they are attached by a secretion. In cedar bark the eggs

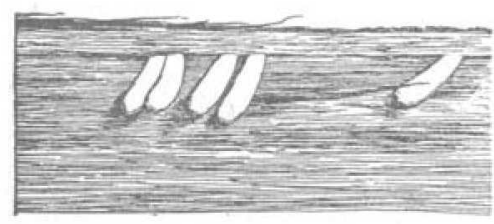

Fig. 28. Paracalocoris hawleyi: lower figure, eggs in bark, $\times 9$; upper figure, one egg, more enlarged (original). deep enough for the egg. Since nymphs are equally common in the spring on poles of this kind, eggs must be laid there in large numbers. The egg stage lasts from nine to nine and one half months.

NYMPH.-Stage I: Length, $1.3 \mathrm{~mm}$. (average of 10); general color light tomato red; a median, variable light line runs from near the cephalic end of the head to near the posterior end of the second abdominal segment, fuint in some but in others distinctly white, bordered laterally on the thorax by clay colored patches. Antennæ with the basal segment slightly clubbed, tomato red and sparsely clothed with hairs, second segment sparsely hairy, white $(2 / s)$ and red $(3 / s)$, third segment sparsely hairy, white $\left(\frac{1}{2}\right)$ and red $\left(\frac{1}{2}\right)$, fourth segment densely hairy, clay color with small white spot at base. Coxa of leg is white, trochanter white, femur red, tibia with three red and three white bands of varying breadth, tarsus white with dark tip, claws dark. Euch abdominal segment bears a row of dark setæ; head and thorax bear irregularly arranged setz. Beak is white with dark tip. Venter is clay color. In a few cases the median line is wanting as well as all white bands, the insect being red with the exception of 4 th antennal segments. The description is for the must typical specimens (Fig. 29).

Stage II: Length, $1.9 \mathrm{~mm}$. General color, slightly darker; median line broader and more distinct; clay colored border patches indistinct; bands on antennæ and legs 

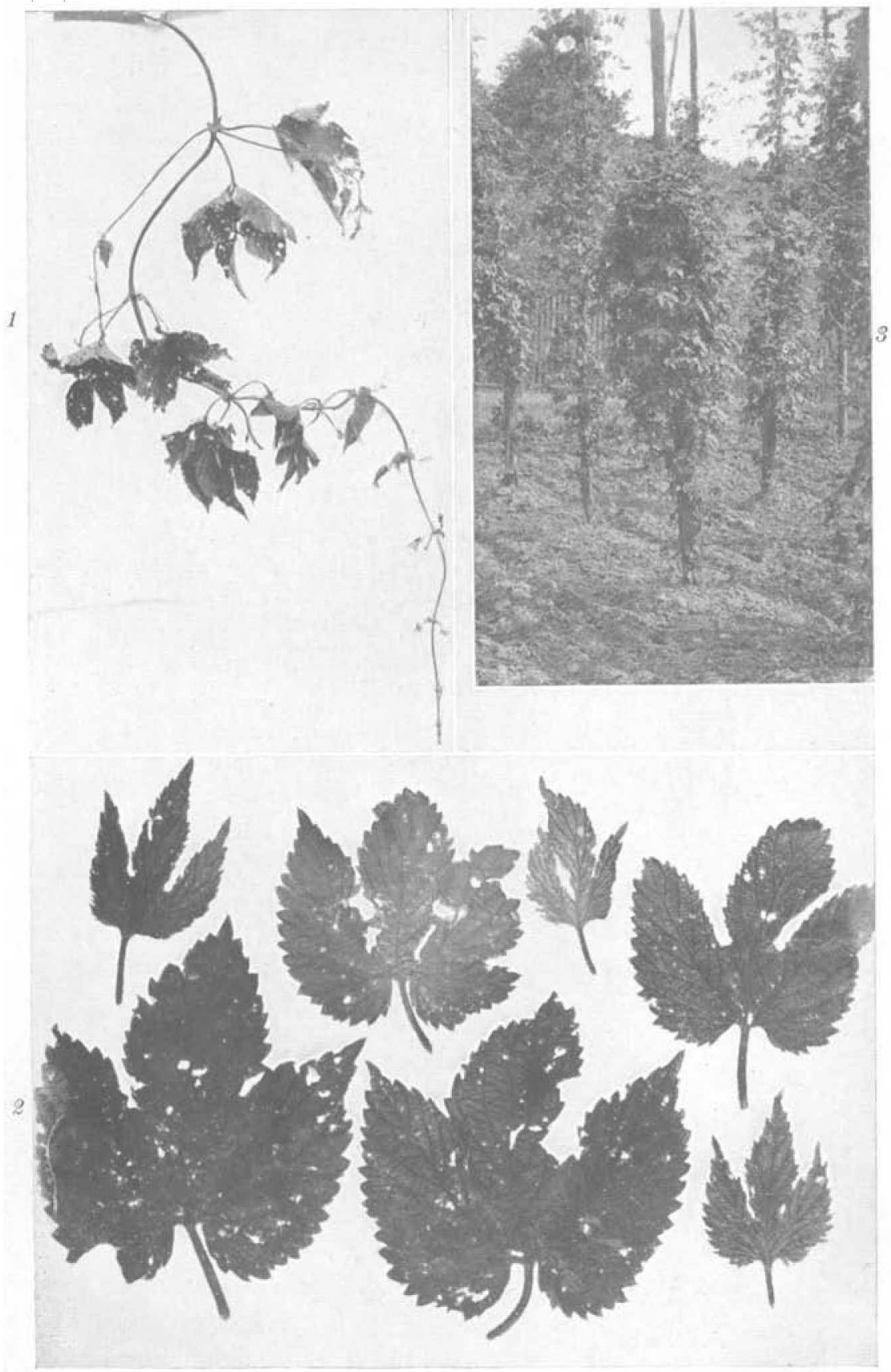

Hop redbug work. 1,2 Injury to leaves; 3 Hill showing vines slipping down the pole. 


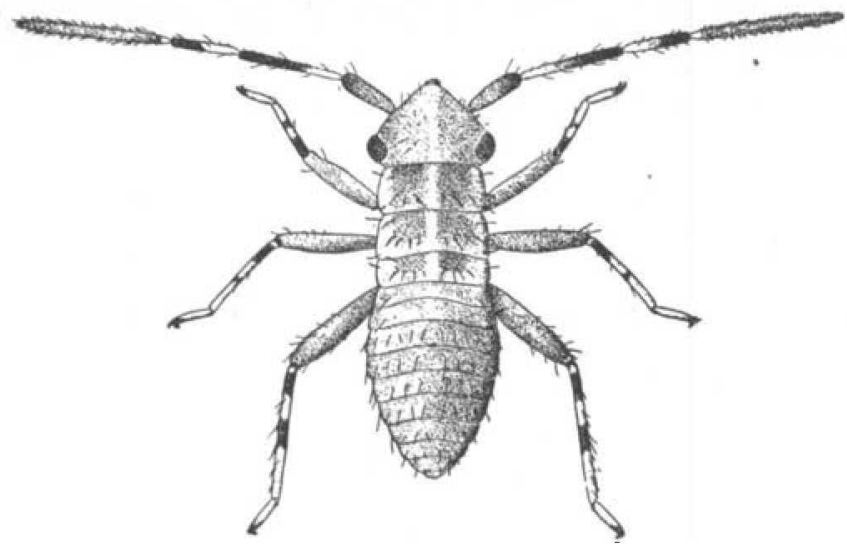

Fig. 29. Paracalocoris hawleyi, first stage nymph, $\times 30$ (original).

more prominent; white spots begin to appear around setre on abdominal eegments; basal antennal segment a darker red and much more hairy; terminal segments lighter except at tip. Aberrant specimens show no median line, no white bands, faint bands on antennæ and legs or faint bands on antennæ and none on legs (Fig. 30).



Fig. 30. Paracalocoris hawleyi, second stage nymph, $\times 21$ (original).

Stage III: Length $2.5 \mathrm{~mm}$. General color same as previous stage; red bands on antenna and legs much darker than body. Wing pads begin to show; white spots around setæ more distinct. Setæ longer and coarser. Some aberrant specimens as before (Fig. 31).

Slage IV: Length $3.1 \mathrm{~mm}$. General color as before. Wing pads brownish and 




Fig. 31. Paracalocoris hauleyi, third stage nymph, $\times 17$ (original).

reaching nearly to third abdominal segment; antennal segments thicker in red than in white areas. Dusky spot shows around gland between third and fourth abdominal segments. Aberrant specimens as before (Fig. 32).

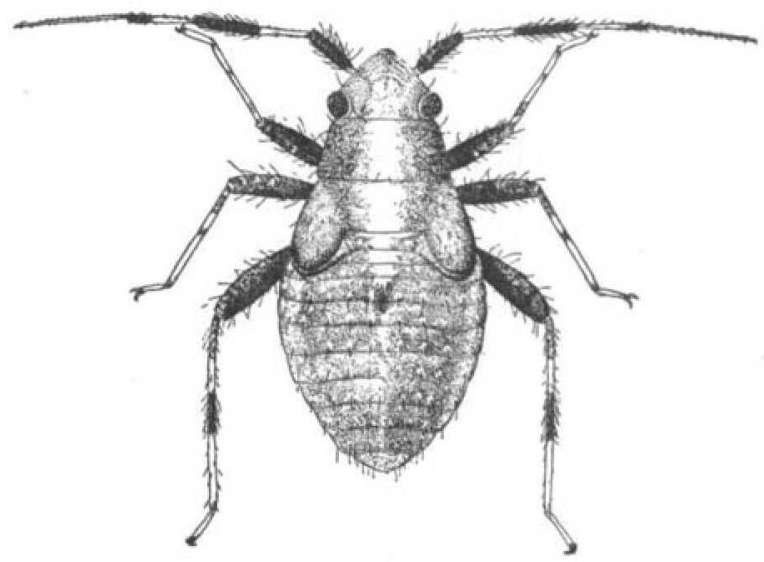

Fig. 32. Paracalocoris hawleyi, fourth stage nymph, $\times 13$ (original).

Slage V: Length $4 \mathrm{~mm}$. There is a wide variation in color; some light red with almost transparent wing pads; some dark red with wing pads and dark spots of legs sepia. Wing pads reach almost midway between fourth and fifth abdominal segments; dusky spot around gland more prominent; two dark spots nay be present on 


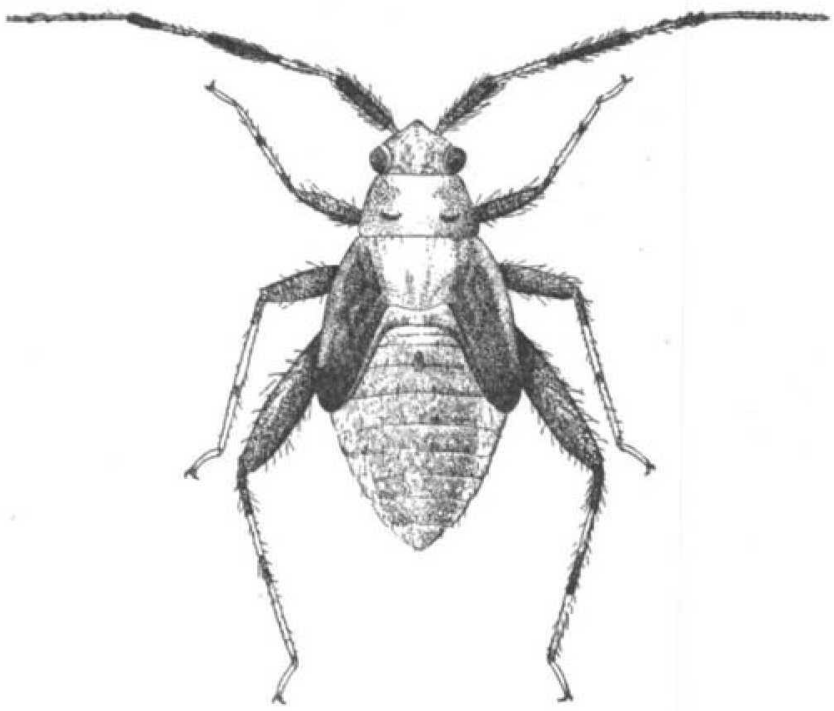

Fig. 33. Paracalocoris hawleyi, ffth stage nymph, $\times 10$ (original).

pronotum. White spots around setre very distinct. As in previous stages there is a wide variation in markings (Fig. 33).

The data on four specimens bred in the year 1915 are given in Table No. 1 .

Table 1.-Thansmormationa And Length on Staaes, 1915

\begin{tabular}{|c|c|c|c|c|c|c|c|c|}
\hline No. & Egg Taken & Hatch & Stage II & Stage III & Stage IV & Stage V & Adult & Egg to Adult \\
\hline $\begin{array}{l}1, \ldots \ldots \ldots \ldots \ldots \ldots \\
3, \ldots \ldots \ldots \ldots \ldots \ldots \ldots \ldots \\
3 \ldots \ldots \ldots \ldots \ldots \ldots \ldots \ldots \\
4 \ldots \ldots \ldots \ldots \ldots \ldots \ldots\end{array}$ & $\begin{array}{ll}\text { May } 21 \\
\text { May } 21 \\
\text { May } 6 \\
\text { May } 6\end{array}$ & $\begin{array}{l}\text { June } 13 \\
\text { June } 13 \\
\text { June } 15 \\
\text { June } 10\end{array}$ & $\begin{array}{l}\text { June } 19 \\
\text { June } 19 \\
\text { June } 20 \\
\text { June } 15\end{array}$ & $\begin{array}{l}\text { June } 21 \\
\text { June } 21 \\
\text { June } 24 \\
\text { June } 22\end{array}$ & $\begin{array}{l}\text { June } 30 \\
\text { June } 30 \\
\text { June } 30 \\
\text { June } 30\end{array}$ & $\begin{array}{l}\text { July } 8 \\
\text { July } 6 \\
\text { July } 6 \\
\text { July } 7\end{array}$ & $\begin{array}{l}\text { July } 14 \\
\text { July } 13 \\
\text { July } 13 \\
\text { July } 12\end{array}$ & $\begin{array}{l}31 \text { daya } \\
30 \text { days } \\
25 \text { days } \\
32 \text { days }\end{array}$ \\
\hline
\end{tabular}

Average; 30.1 days.

Breeding was carried on in petri dishes in a well ventilated, unheated field laboratory. Pieces of bark with eggs were placed in the dishes. These were examined and after hatching fresh food was added each day.

ADULT.-The adult is about $6 \mathrm{~mm}$. in length, fusco-piceous to piceous with hemelytra sordid hyaline or pale yellowish and cuneous reddish. Pubescence is sparse.

Technical descriptions of the species and four varieties are published in the December (1916) issue of the Annals of the Entomological Sociely 
of America by W. L. McAtee who examined the material sent him by H. H. Knight. Of these four varieties, Paracalocoris hawleyi var. hawleyi and $P$. hawleyi var. ancora are the common forms on the hop. The former has a pale lateral stripe on the corium (Fig. 34), which is not present on the latter. $P$. hawleyi var. ancora is much more numerous than the other form (Fig. 35).

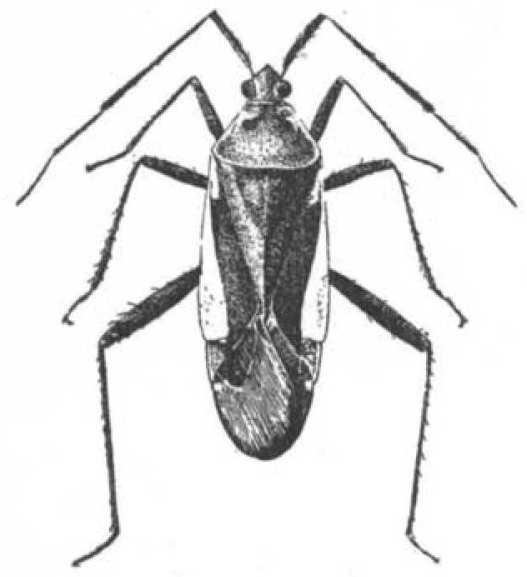

Fig. 34. Paracalocoris hawleyi, var. hawleyi, about $\times 7$ (original).

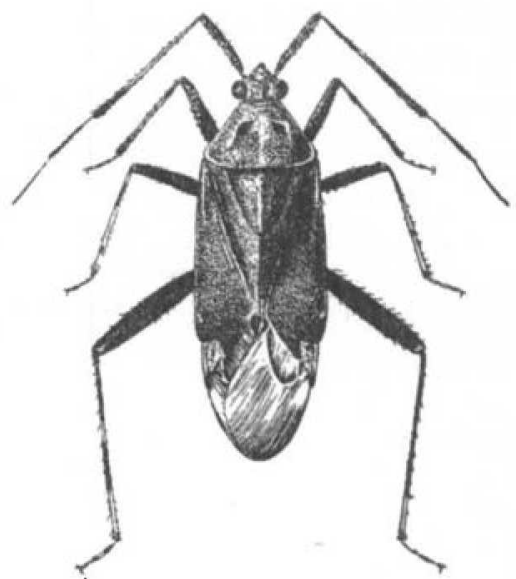

Fig. 35. Paracalocoris hawleyi var. ancora, about $\times 7$ (original).

\section{HABITS}

The nymphs are active and, when disturbed, crawl rapidly among the leaves and vines and into the cracks of the hop poles. At rest, they may usually be found on the under sides of the most tender leaves - often five to ten on a leaf and one hundred or more to a hill. When jarred, they drop straight down to a lower leaf to which they often adhere by everting the end of the alimentary canal. They prefer the tender leaves and vines and are, therefore, in August, more numerous near the tops of the poles.

The adult, when disturbed, drops a short distance and then flies gradually downward in a zig-zag course. At rest they may be found on the vines, poles, and on the upper and under surfaces of the leaves.

\section{Seasonal History}

Over-wintering eggs are laid in hop poles from the middle of August till Septcmber, as determined by dissected specimens. These hatch the following year from June 1 till nearly the first of July. The nynuphal period lasts about thirty days, adults beginning to appear about the first of July. Nearlv all are winged hv the first of August. 
Adults may often be found in September but eventually die. There is no evidence that they survive the winter.

\section{Natural Enemies}

Predators.-The Pentatomid, Apeteticus maculiventris Say, is predaceous in both the nymphal and adult forms on the immature stages of the hop redbug. Eggs and nymphs of this form are common on the hop in July and August.

Onc of the Nabidæ, Reduviolus subcoleoptratus Kirby, which is present on many plants near the hop yards, has been found feeding on the nymphs of the hop redbug.

A predaceous red mite (Trombidium sp.) has been observed on several nymphs.

The adults, Paracalocoris hawleyi, of this species have been found feeding on nymphs of their own kind. Nymphs have also been found feeding on the pupa of Ania limbata (Geometridæ), the larva of Lysia cognataria (Geometridæ), the larva of Hypena humuli (Noctuidæ), and the pupa of Malacosoma americana (Lasiocampidæ).

\section{Control}

In 1915 it was decided to test a tobacco extract spray on the hop redbug. To this end nicotine sulphate (Black leaf 40 ), 1 pint to 100 gallons of water, with 6 pounds of soap, was applied on July 17. The material apparently killed at once. However, as fifty-six live nymphs were found on six sprayed hills on July 19 another spray was applied. This time Black leaf 40,1 pint to 100 gallons of water with 4 pounds of soap was used. On July 20 , six hills had sixteen dead and eleven live nymphs present, but on July 21 no dead nymphs could be found. This is due to the fact that the nymphs, after the spray material dries, drop off. The following experiment shows that whenever nymphs are reached they are killed. On July 19, when field experiments were carried on, forty sprayed specimens were placed in a laboratory cage. None revived. Thirty specimens sprayed with an atomizer were all killed when the same solution as used in the field was applied.

Since nicotine sulphate, $\frac{3}{8}$ pint to 100 gallons of water with 4 pounds of soap, will control the hop aphis (Phordon humuli Schrank), the writer tried it to see the effect on the hop redbug. Leaves with redbugs from vines sprayed in the field were taken into the laboratory. Six of fifteen specimens were alive the following day. Seven of thirty redbugs sprayed in the laboratory were alive twenty-four hours later. When the bug became attached to the glass dish by means of the solution, it was invariably killed-otherwise it often recovered. To prevent sticking, filter paper was placed in the bottom of the dish and the 
bugs were sprayed with an atomizer. Six of ten were killed. It is evident that this strength is insufficient for the control of the redbug.

To be successful, spraying should be done about the third week in June, before the vines have produced large arms. Most of the nymphs will have hatched and can be reached easily at this time. Later, when the vines become dense and many have slipped down the poles, it is impossible to reach all of the bugs hidden among the mass of leaves. Poles as well as vines should be drenched, as many nymphs take refuge in the cracks and under projecting bark. Because of the agility of the bugs, it is wise to spray a hill from opposite sides at the same time when possible. Winged forms fly before they can be reached by a spray.

\section{Literature Cited}

Theobald, F. V. 1895. Notes on the needle-nosed hop bugs. Jour. S. E. Agr. Col. No. 2, pp. 11-16.

McAtee, W. L. 1916. Key to the nearctic species of Paracalocoris (Heteroptera; Mirida). Ent. Soc. of Amer. Annals. IX, 377-380 (December).

\section{AMPHISCEPA BIVITTATA SAY, IN ITS RELATION TO CRANBERRY ${ }^{1}$}

By H. B. Scammel, Entomological Assistant, Deciduous Fruit Insect Investigations

\section{INTRODUCTION}

The literature on this Fulgorid is somewhat barren in so far as the subject of its life history is concerned, and the following data are set forth as a contribution dealing chiefly with biological notes made in the course of the cranberry insect investigations being conducted by the Bureau of Entomology in New Jersey. Mr. H. K. Plank assisted the writer during two field seasons and to him he is indebted for making the photographs used in illustrating this paper.

The insect has been known as the "broad winged leaf-hopper" (1)" but that appellation scarcely is applicable because, at least on cranberry, it is not a pest of the foliage but of the woody stems, namely, the runners and uprights. The common name which is here suggested, inasmuch as the species is associated frequently with cranberry, a cultivated crop, is the cranberry vinehopper.

\section{ECONOMIC IMPORTANCE}

Dr. John B. Smith (2) recorded Amphiscepa bivittata Say from several places in New Jersey and made a statement to the effect that it did

1 Published by permission of the Secretary of Agriculture.

2. Reference is made by number to "Literature cited," page 556. 